October 6, 2001

\title{
Subsidiarity as a Constitutional Principle in Environmental Policy
}

Prof. Dr. Jürgen G. Backhaus

Krupp-Stiftungsprofessur für Finanzwissenschaft und Finanzsoziologie

Staatswissenschaftliche Fakultät

Universität Erfurt

Nordhäuser Str. 63

99089 Erfurt

tel: $+49-361-737-4550$

fax: $+49-361-737-4559$

email: juergen.backhaus@uni-erfurt.de

Paper prepared for presentation at the meeting of the

Arbeitskreis für Politische Ökonomie

October 4-6, 2001

Universitätskolleg Bommerholz 


\title{
Subsidiarity as a Constitutional Principle in Environmental Policy
}

\begin{abstract}
The principle of subsidiarity has become more widely known with its prominent adoption in the Maastricht Treaty. The principle is, however, deeply embedded in the history of political economy, notably in the continental European tradition. In this tradition, it has the status of a principle in constitutional political economy, i.e. it is a principle that affects policy design as opposed to policy choice. This article emphasizes the constitutional political economy aspect of the principle and illustrates its usefulness with respect to environmental policy design.
\end{abstract}

Keywords: environmental taxation, Maastricht Treaty, subsidiarity principle JEL codes: H10, K10, Q20, Q30 


\section{Subsidiarity as a Constitutional Principle in Environmental Policy}

\section{Introduction}

The principle of subsidiarity, since it became part of the treaty of Maastricht and thereby of European constitutional law, has received a lot of attention. Its relationship to ecological issues, however, has to my knowledge rarely been explored. Subsidiarity is a perfectly generalizable principle of organization. It can apply to all areas of policy, financial, agricultural, technological, education, defense, economic development and, of course, environmental policy. The principle of subsidiarity is an organizing principle. Taken as such, it is silent about the specific purpose, direction or content of a particular policy. Whatever be the purpose of the policy, the principle of subsidiarity requires that it be carried out within that context which is the smallest viable one in which the objective can successfully be attained. When a task is too complicated for a small unit such as an office or a firm to be successfully performed, that unit has to be augmented to the point where the task can be effectively performed. Likewise, if an organization is too large to successfully handle particular problems as its procedures may be too cumbersome, as it lacks sufficient detailed information or experiences repeated recurrence of problems it once has tried to settle, then a different organizational form must be found, preferably an existing one, which is closer to the problem at hand and able to carry out the policy at hand. It goes without saying that with the shift in responsibility will also travel the access to resources with which to carry out the task.

\section{Aspirations and Policy Goals: Enforced and Selfenforcing Rules and Policies}

In constitutional economics, we can distinguish between different types of approaches, notably those that need to be enforced and those that are designed to be selfenforcing. Given the difficulties enforcement agencies have in enforcing rules laid down and sometimes agreed to beforehand, there is always a preference for self-enforcing rules.

Rules have a better chance of being self-enforcing if there is a close match between the functions of a particular unit and the means and responsibilities to serve this function, where the rules have the purpose to ensure a proper use of the means and responsibilities with a view to performing the functions in question. The crucial issue then is to define that unit which is most appropriate for fulfilling a particular function. Very often in constitutional public choice, 
this question is not addressed head on. Typically, we start from the assumption that there be a state or a commonwealth, without exploring the question of which domain this commonwealth or state should actually occupy, and in relation to what other public bodies. Therefore, the first section of part 2 is devoted to an in-depth discussion of the subsidiarity principle. It is shown, in particular, that the principle has a strong history in European thought, and that it therefore deserves to be systematically relied upon in constitutional economics.

\section{Subsidiarity}

The principle of subsidiarity has earned a solid position in European intellectual history. Since due to its incorporation into the Maastricht treaty ${ }^{1}$ it has become international law, it is worth briefly retracing its intellectual history.

\subsection{Historical Context and Theory}

This short section tries to clarify the meaning of the principle of subsidiarity - which is far from unambiguous - and to explain some of its implications in the context of European unification and the accompanying legal discourse.

Perhaps one of the earliest formulations of the principle of subsidiarity, which is at the same time one of the first formulations of a full scale state welfare program, can be found in Christian Wolff's Principles of Natural Law, published in 1754. There, in '1022, he states the following:

In order to lead one's life with decency, it is necessary, that the destitute and the beggars be provided with what they basically need, and that therefore the subjects will not be burdened with too much charitable giving. It has to be carefully determined what the natural law prescribes for charity. Houses of order are to be established where those can work who, although they are able to work would rather prefer to keep begging. Similarly, houses for the destitute need to be established, where those will be fed who cannot work for their own livelihood,

\footnotetext{
1 The most detailed statement of the principle can be found in article 3 B (2) of the EC Treaty: In some areas which do not fall within the exclusive competence, the community shall take action, in accordance with the principle of subsidiarity, only if and insofar as the objective of the proposed action cannot be sufficiently achieved by the member states and can therefor, by means of the scale or effects of the proposed action, be better achieved by the community.
} 
and who have no relatives or friends who could take care of their needs: also hospitals, where the destitute poor will be fed and sometimes cured. Likewise orphanages, where poor orphans be educated: and finally schools for the destitute, where the children of poor parents will be taught for free in those matters, that are necessary and useful for them. ${ }^{23}$

Several elements of this exposition are particularly noteworthy. This is first of all the scope of the program of the welfare state, including measures in order to alleviate the consequences of sickness, unemployment, poor health, orphanage and more generally poverty, in which case access to public schools is guaranteed. Yet the rationale for this government welfare program, as Wolff explicitly states, is to keep the burden of the welfare taxes to be borne by citizens at a minimum. The welfare state intervenes if and because this is the least expensive way to alleviate the problem. Equally noteworthy is the precise circumscription of the instance under which the welfare state has to intervene, $\underline{\text { i.e. }}$ if the person in need has no "relatives or friends who can take on the satisfaction of his needs". The welfare state, therefore, is only subsidiary to the traditional bonds of family and friendship. Yet it would be wrong to think of the principle of subsidiarity as conceived by Christian Wolff as one built around individualism. It is not the individual which is considered the smallest unit of support (of others), since that would not have been a realistic description of the political economy of his time. Rather, Wolff puts forth a different economic constitution of his welfare state, with the big households comprehending the extended family as the nuclear entity of which the larger economy is composed:

It can be readily seen that single houses cannot sufficiently provide themselves with what gives satisfaction of needs, comfort, and pleasure, in fact even what is needed for their welfare, nor can they safely profit from their rights and from what

\footnotetext{
2 "Das Leben gehörig hinzubringen, wird auch erfordert, dass man vor die Dürftige und Bettler besorge, was zur Notdurft des Lebens nötig ist, und, damit die Untertanen nicht gar zu sehr mit Almosen geben beschwert werden, ist in sorgfältige Betrachtung zu ziehen, was das Naturgesetz von den Almosen feste setzt (' 488.sequ.). Daher sind Zuchthäuser aufzubauen, worin diejenigen zur Arbeit angehalten werden müssen, welche, ob sie gleich Arbeiten könnten, doch lieber betteln wollen; ingleichen Armenhäuser, worin man die dürftigen ernährt, die sich durch Arbeiten das nicht zu erwerben im Stande sind, was sie zur Lebensnotdurft gebrauchen, und keine Anverwandten oder Freunde haben, welche sich ihrer Bedürfnisse annehmen könnten; noch ferner Krankenhäuser, worin kranke Arme teils ernährt, teils geheilt werden; So auch Waisenhäuser, worin man arme Waisen erzieht; endlich Armenschulen, in welchen man die Kinder armer Eltern umsonst in demjenigen unterrichtet, was ihnen zu wissen nötig und nützlich ist."

3 Christian Freiherr von Wolff, Grundsätze des Natur- und Völckerrechts. Halle: Renger, 1754, III, 2.1 .
} 
they can rightfully expect from others, nor can they be sure to protect themselves against the violence of others. It is therefor, necessary, to provide through common forces what single houses cannot get by themselves. For this purpose societies have to be formed ('836). ${ }^{45}$

We realize then, that in Wolff's conception the principle supporting the unit of the welfare state was the house, i.e. the classical household or micro-economy; only if it failed, a larger politico-economic unit had to intervene. The interesting question then is what form this intervention was supposed to take. The answer is already implicit in Wolff, but a more explicit statement can be found in the writings of another authority on political thought in continental Europe writing about a hundred years after Wolff:

Of course, from the need to have anyone provided with basic necessities, it follows by no means that it is the state that has to do the providing. To the contrary, the state will look at this need as it does at any other demand on the part of his citizens. In particular, the state has to lend a helping hand through policing and regulating if this cannot be accomplished through private efforts. As a rule, this will not be necessary if the general provisions have been taken that allow the citizens to earn income and wealth and to use their means effectively. ${ }^{67}$

In brief, Mohl suggests that the mere existence of needs of its citizens are an insufficient reason for the state to directly satisfy those needs. In general, the state, rather than satisfying needs of its citizens directly has the task to create the conditions under which the citizens can accumulate sufficient wealth in order to satisfy their needs themselves. Note that this application of the principle is twofold, and twice correct. On the one hand, Mohl correctly 4' 972. "Wir erkennen sehr leicht, dass einzelne Häuser sich selbst dasjenige nicht hinreichend verschaffen können, was zur Notdurft, Bequemlichkeit und dem Vergnügen, ja zur Glückseligkeit erfordert wird, noch auch ihre Rechte ruhig genießen, und was sie von andern zu fordern haben, sicher erhalten, noch auch sich und das ihrige wider anderer Gewalttätigkeit schützen können. Es ist also nötig, dasjenige durch gemeinschaftliche Kräfte zu erhalten, was einzelne Häuser vor sich nicht erhalten können. Und zu dem Ende müssen Gesellschaften errichtet werden (' 836)."

5 Wolff 1754, III, 2.1.

6 "Natürlich folgt aus dieser Notwendigkeit des Besitzes genügender Lebensbedürfnisse noch keineswegs, dass sie gerade der Staat zu liefern habe. Im Gegenteil wird er sich zu diesem Bedürfnis wie zu jedem anderen Verlangen seiner Bürger verhalten. Er hat also namentlich polizeiliche Hilfe nur dann zu gewähren, wenn bei der größeren Allgemeinheit eines Bedürfnisses auch die Unmöglichkeit vorliegt, dasselbe mittels Privatanstrengung zu befriedigen. Und in der Regel wird Letzteres nicht der Fall sein, wenn die allgemeinen Maßregeln zur Erwerbung von Vermögen gehörig getroffen sind und benützt werden."

7 Robert von Mohl, Die Polizeiwissenschaft nach den Grundsätzen des Rechtsstaates, Tübingen, 1844 (2), pp. 265-266. 
identifies the state as the better provider of the (mostly legal) infrastructure which allows its citizens to prosper and accumulate wealth in order to satisfy the needs of themselves and their dependants. He correctly assumes that the provision by the state will detract from this objective, since the provision by the individual households will be more cost effective than the provision by the state which would, by necessity, have to be financed through taxes to be borne by the tax paying households. Consequently, the state is responsible for providing the infrastructure in which the individual households can prosper. Since, on the other hand, provision of welfare services and the satisfaction of needs can be better targeted and more effectively rendered by the (larger) households, it is to them that the task also falls, relieving them of the otherwise necessary tax burden. In applying the principle of subsidiarity, it is of pivotal importance to continuously consider both sides of the coin, the expenditure side and the revenue side. The determination of the primary and the subsidiary service entity can only be accomplished if both expenditure and revenue factors have been properly and completely taken into account.

A more recent and perhaps the most widely read formulation of the principle of subsidiarity is contained in a Papal letter (encyclic) named after the two beginning Latin words Quadrogesimo anno in section 79 of the encyclic of 1931. The text reads:

And since what an individual can accomplish through his own initiative must not be taken away from him and accorded as a collective task to the state, so similarly it violates the principle of justice that the bigger and higher authority claim a task that smaller communities can accomplish well. This would be extremely disadvantageous and confusing for the entire social order. Every social activity, to be sure, is subsidiary by its own nature and on its own terms. It is supposed to support the different organs of the bigger social body, which however may not absorb or destroy the smaller entities. ${ }^{8} 9$

\footnotetext{
8 "Wie dasjenige, was der Einzelmensch aus eigener Initiative und in seinen eigenen Kräften leisten kann, ihm nicht entzogen und der Gesellschaftstätigkeit zugewiesen werden darf, so verstößt es gegen die Gerechtigkeit, das, was die kleineren und untergeordneten Gemeinwesen leisten und zum guten Ende führen können, für die weitere und übergeordnete Gemeinschaft in Anspruch zu nehmen; zugleich ist es überaus nachteilig und verwirrt die ganze Gesellschaftsordnung. Jedweder Gesellschaftstätigkeit ist ja ihrem Wesen und Begriff nach subsidiär; sie soll die Glieder des Sozialkörpers unterstützen, darf sie aber niemals zerschlagen oder aufsaugen."

9 Cited after Roman Herzog, "Subsidäritätsprinzip und Staatsverfassung". Der Staat, 3, 1963, pp. 339423 (400).
} 
In this formulation, the subsidiarity principle appears rather matter-of-factly as a restatement of an old principle in political theory and also church doctrine. Secondly, it receives an organic twist which blurs its sound economic interpretation. If a community can reasonably discharge its duties, a larger community (of which it is conceivably a part) should not take over these duties as a matter of (ethical) principle. In this formulation, no mention is made of the costs and benefits to the larger and the smaller community respectively, nor to the costs and benefits facing other smaller communities being part of the larger whole. It is not surprising that the formulation from the encyclic, rather than the traditional formulation, has given rise to much controversy and contradictory applications.

Yet the economic core of the principle is readily crystallized. In order to optimize the performance of the larger political entity, primary liability for the solution of problems lies with the smallest functional unit. This need not be the lowest functional unit in a hierarchical sense. This smallest functional unit can be a single unit or a group of such units as shown in the quote from Wolff, these units can be linked by friendship, neighborhood, a common religion, history or some other such link. The concept of joining several small units may be referred to as lateral subsidiarity.

In the clear case of insufficiency of a particular level, the nearest functional one needs to be found. The search can go either up or down, depending on where one starts. If a particular province e.g., cannot adequately solve e.g. an environmental problem, it might look at a cooperation with: a) another province (lateral subsidiarity), or b) the nation state or the European Community (upwards subsidiarity), or c) the local communities inside the province, where the problem is most urgent (downwards). The situation might arise where the provincial government takes care of the environmental problem for the smaller communities, whereas the larger communities or those where the environmental problem is most urgent take the matter into their own hands.

It should be emphasized that this principle provides a pattern of thought in order to delineate public responsibilities. The historical survey shows the principle of subsidiarity to be a long standing constitutional principle which actually dates back to the very beginnings of constitution writing based on natural law systems. The natural law source also makes the principle an integral part of church teachings. In its original formulation, the principle of subsidiarity is a constitutional principle determining the definition and delineation of rights 
and responsibilities of private bodies on the one hand and public bodies on the other. This is, e.g. still the case for the role of the principle in the German Basic Law (article two). In the Maastricht Treaty, the principle primarily (but not exclusively) is used to define the relative responsibilities of the European Communities on the one hand and member states or parts of member states (in the German and Belgian case federal states or 'gewesten') on the other. In the tug of war between the community and the member states, where the community tries to expand its programs while these attempts are sometimes met with resistance on the part of at least some of the member states or parts thereof, the principle has assumed a substantial importance. It is enforceable and regularly enforced. ${ }^{10}$

In brief we can interpret the principle of subsidiarity as an economic principle of functional organization. First, the function needs to be clearly defined. Secondly, that organizational unit needs to be defined in terms of a constitutional economic analysis determining which unit can best fulfil this function. A third step will necessarily consist in finding a legal counterpart to the organizational unit defined in this way.

\subsection{Lateral Subsidiarity}

Perhaps the most difficult concept in this context is the notion of lateral subsidiarity. All minds are trained to think in terms of analogies and parallels, and it is difficult to conceive of putting bodies of different legal and political status together into one common co-operation. Yet, in the environmental context where historical and political developments transcend geographical and ecological reasons, such cooperations with a binding legal form are perfectly normal. By way of example, the Lake of Constance is a condominium of one republic (Austrian), two federal German states (Bavaria and Baden-Württemberg), and the Swiss canton of Thurgau. In cooperations between highly centralized countries such as France or the Netherlands and highly decentralized countries such as Belgium and Germany, many lateral forms of subsidiarity can develop.

\section{Subsidiarity and Environmental Policy Design}

The area of environmental policy is vexed with design issues, since environmental problems rarely correspond to political jurisdictions which could be the locus of policy formation and

$10 \mathrm{I}$ am, however, not aware of any rulings on the part of the European court of justice. There is extensive jurisdiction by the German constitutional court in Karlsruhe. 
execution. Consider a river basin. A river and its tributaries can originate in distant locations that are extremely remote from the site of the river mouth or delta, where the river tends to be an important economic factor, typically the site of a harbor. Consider the Danube river. Two very small rivers, the Brigach and Breg come together at Donaueschingen, at 2,850km from the Danube's entry into the Black Sea. Meanwhile, the river disappears altogether under the surface and even contributes part of its water to the river Rhine. It becomes an economic factor with important navigation still in Germany, provides hydro-electric power and regulation in the common and controversial Slovak-Hungarian project and then clearly dominates the landscape and livelihood along its course. Countries with very different economic systems and economic styles are being connected, the river basin is partly within the European Union, partly within countries that are likely to accede to the European Union relatively soon and partly in countries that are less likely to do so in the foreseeable future. Not only are the issues raised for environmental policy with respect to the river basin of the Danube very varied; so are the political jurisdictions that would have to be responsible for formulating such policies.

Alternatively, consider mountain ranges. Typically, ecological conditions can be drastically different on either side of the mountain range, as the mountain ranges tend to also serve as climatic divides. Climatic divides will typically also be responsible for economic, cultural, social, historical and any number of other differences. Thirdly, consider water reservoirs. They can be large and underground, subterraneous under many different jurisdictions. Alternatively, they can be at the surface and have for thousands of years divided entire civilizations. With modern technologies, this is now rapidly changing, implying that traditional forms of decision-making, reflecting as they do historical technological constraints may be due for an overhaul. In the case of the oceans, this is clearly important for international maritime law which no longer is merely an issue of war or peace and the freedom of international trade. Fourthly, climate units comprise different continents and, by implication, different jurisdictions, economic, political and cultural systems. Fifthly, cultural ensembles as expressions of the man-made environment defy attempts at designing effective jurisdictions as they necessarily involve the interests of many different generations, who all contributed or participate differently in the cultural heritage.

Given these daunting tasks of environmental policy design, the principle of subsidiarity plays a crucial role in defining an appropriate body or mechanism or decision rule by which a 
particular policy area with respect to a particular environmental entity, such as a river basin, a mountain range, a water reservoir, a climate unit or a cultural ensemble can be tackled. We need to start with a clear definition of the function that a set of policies is supposed to fulfil, such as the sustainable development in the interest of all citizens forming part of a river basin. Then one needs to identify those entities which can most effectively discharge of this function in their respective part of the river basin. Thirdly, one needs to assemble all these entities into a concert of decision-making so as to be able to design a coherent policy framework in which the function then can be discharged by the singular elements. It is possible, even likely, that decisions will have to be taken at different echelons or with respect to different policy areas carved out of the general one. The principle of subsidiarity will thus serve to constitute the framework in which for any given ecological entity policy design can take place. In this, the principle is a constitutional principle in political economy, serving to create competencies for policy design.

\section{Conclusion}

In this article the principle of subsidiarity has been developed as an organizational principle to be used in constitutional environmental economics. Constitutional environmental economics is that part of economics in which we try to set out the structures in which decision making processes with respect to ecological units can take place. The principle of subsidiarity has been shown to help in defining relevant organizational units in which political decision making can take place in order to ensure an efficient and sustainable management of specific units.

It is by no means unusual that a central government may have to cooperate with a state government (such as between the Netherlands and the state of North Rhine Westphalia, were such cooperations are common between The Hague and Düsseldorf), a district or even a county or city. In Switzerland and Belgium, many tasks which are normally reserved for the central government fall to the canton (Switzerland) or de gewest (Belgium). Germany has a traditional system, since the reforms by Stein and Hardenberg in the first decade of the 19th century, emphasizing local independence and responsibility, even the residual right of taxation. It is true that central governments are often reluctant ${ }^{* *}$ to enter into consultations with foreign governments at lower levels. But this is what the principle of subsidiarity requires. Logically the subsidiarity principle requires the co-operation of the smallest viable

\footnotetext{
. They tend to be ill equipped to do so.
} 
units, and if a country does not provide for local authority, that authority has to be found at which ever is the lowest level. In highly centralized countries such as France and the Netherlands, the principle of subsidiarity will therefore point towards the center, whereas in highly decentralized countries such as Belgium, Germany and Switzerland it points to local bodies. 


\section{References}

Backhaus, J. 'Justitiable Bedarfsprüfung im Genehmigungsverfahren: Ein Lüneburger Vorschlag', in: J. Finsinger und J. Simon (Hrsg.) Recht und Risiko. München: VVF, 1988, S. 96-112.

Herzog, R. 'Subsidiarititätsprinzip und Staatsverfassung', Der Staat, 3, 1963, pp. 339-423 (400).

Vaubel, R. Das Sozialpolitische Abkommen von Maastricht widerspricht dem Subsidiaritätsprinzip, Universität Mannheim, 23.24.4.1993.

Vaubel, R. 'A Public-Choice View of the Delors Report', in: Vaubel, R. and Willet, T.D. (eds.), The Political Economy of International Organizations. A Public Choice Approach. Boulder, Col.: Westview Press: 306-310.

Wolff, Chr. Grundsätze des Natur- und Völckerrechts, Halle: Renger, III, 2.1, 1754. 